УДК 616.89-008.441.33-083.88

DOI 10.11603/2411-1597.2019.4.10837

\title{
ПЕРЕДОЗУВАННЯ ОПІОЇДАМИ: ЯК НАДАТИ ДОМЕДИЧНУ ДОПОМОГУ
}

\author{
T. B. Koca
}
Комунальна установа "Територіальне медичне об'єднання "Обласний иентр екстреної медичної допомоги та медицини катастроф" Запорізької обласної ради Тернопільський національний медичний університет імені І. Я. Горбачевського МОЗ Украӥни

У статті описано порядок надання домедичної допомоги особам при підозрі на передозування опіоїдами.

\section{FIRST AID IN OPIOID OVERDOSAGE}

\author{
T. V. Kosa \\ Municipal Institution of Zaporizhzhia Regional Council "Territorial Medical Association \\ "Zaporizhzhia Regional Emergency and Disaster Medicine Center \\ I. Horbachevsky Ternopil National Medical University
}

The article describes the procedure for providing of first medical aid to individuals with suspected opioid overdose.

Вступ. Термін «наркоманія» походить від двох грецьких слів: «narke» - затьмарення свідомості, заціпеніння, оніміння, параліч; «mania»-смерть, манія, божевілля, безумство, пристрасть. Це хворобливий психічний стан, зумовлений хронічною інтоксикацією внаслідок зловживання наркотичними засобами, що віднесені до таких конвенціями ООН чи Комітетом 3 контролю за наркотиками при Міністерстві з охорони здоров'я України до тієї чи іншої групи і характеризуються психічною або фізичною залежністю від них. Наркоман - це людина, яка регулярно вживає наркотичні речовини і якій лікарі встановили діагноз «наркоманія».

Епідемія наркоманії в Україні набуває все більшого розмаху: за даними експертів, на сьогодні кількість споживачів психоактивних речовин сягає понад 500 тис. осіб переважно молодого віку. У світі нині немає жодної країни, яка б могла доказово заявити, що їй вдалося подолати це зло. На жаль, не становить винятку й Україна (рис.).

Якщо порівнювати загальні рівні смертності у європейських країнах, то в Україні, Ісландії, Ірландії та Люксембурзі ці показники є одними з найвищих у Європі, де на мільйон жителів віком від 15 до 64 років припадає понад 100 смертей від наркотиків.

(c) T. B. Koca, 2019
Близько 346 тис. українців вживають наркотики ін'єкційно, а наркозалежних, за офіційними даними, нараховується більше мільйона осіб. У 2017 р. зафіксували 389 випадків передозування наркотиками лише серед неповнолітніх.

Актуальними $\epsilon$ знання про надання домедичної допомоги особі внаслідок передозування наркотичних препаратів. Саме тому прийнято наказ МО3 від 16.06.2014 р. № 398 «Про затвердження порядку надання домедичної допомоги особам при невідкладних станах» і додано «Порядок надання домедичної допомоги особам при підозрі на передозування опіоїдами». Наказом МОЗ від 08.10.2018 р. № 1833 були внесені зміни.

Основна частина. До групи опіоїдів належать: «ширка», усі різновиди героїну, кодеїн і метадон. Подібні за своєю дією деякі медикаменти для наркозу і заспокійливі ліки (психотропні препарати: «Радедорм», «Реладорм», «Реланіум», «Фенобарбітал»).

У цій групі багато спільного: всі опіоїди діють на одну й ту ж частину мозку, вони дуже небезпечні при поєднанні з алкоголем і снодійними, здатні викликати передозування. Різні наркотики цієї групи відрізняються силою, концентрацією і тривалістю дії. Тому дози різних наркотиків для однієї людини будуть різними. Між «нормою» і смертельною дозою різниця 


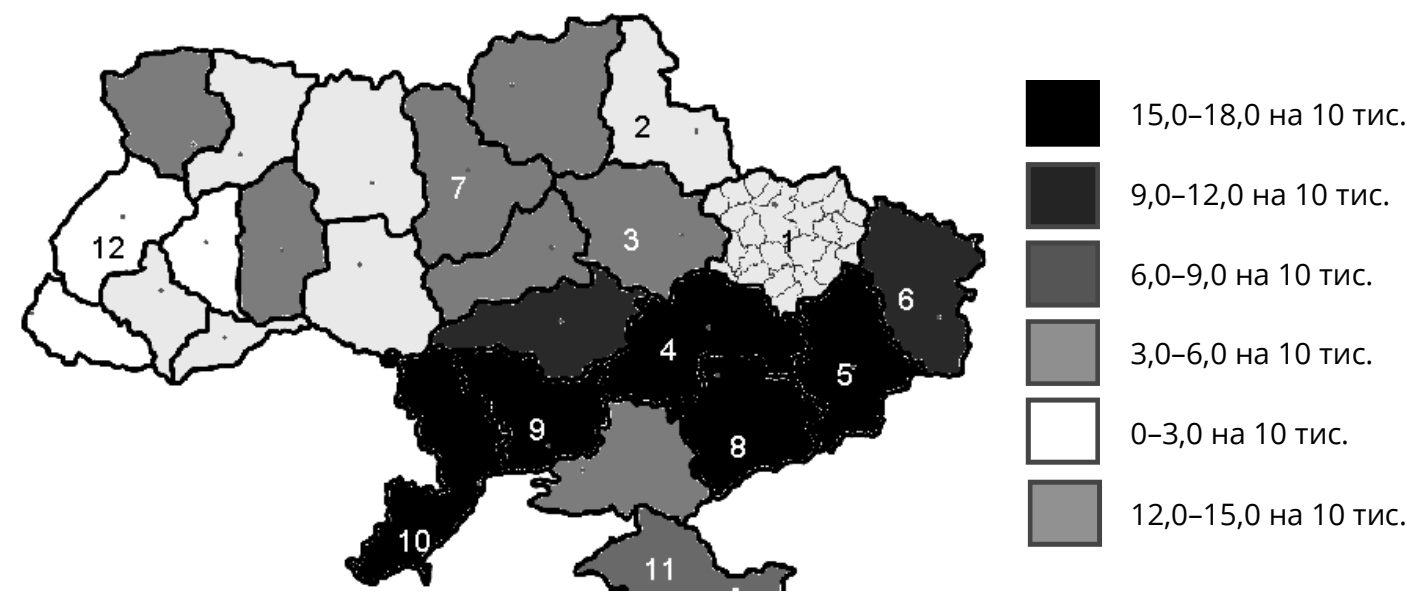

Рис. Розповсюдженість наркоманії за регіонами України.

зовсім невелика. Крім того, один і той самий наркотик на різних людей діє по-різному - те, що нормально для одного, смертельно для іншого.

Ознаки передозування [1]:

- ускладнене/пригнічене дихання (менш як 1012 вдихів за хвилину) або зупинка дихання;

- послаблення або зникнення пульсу;

- зниження рівня або втрата свідомості;

- суттєве звуження очної зіниці (діаметр менш як 2 мм);

- бліді шкірні покриви, ціаноз губ та кінчиків пальців.

Смерть від передозування може настати внаслідок таких причин [1]:

- паралічу дихання;

- зупинки серця;

- неможливого дихання через блювання чи западання язика.

\section{Дії рятувальника при виявленні ознак передо-} зування:

- впевнитися у власній безпеці та оцінити ситуацію;

- провести огляд постраждалого, визначити, притомний чи непритомний;

- покликати на допомогу оточуючих;

- вкласти пацієнта на тверду, рівну горизонтальну поверхню;

- перевірити наявність дихання за допомогою прийому «чути, бачити, відчувати» (наявність дихання визначати протягом 10 с);

- якщо виникли сумніви щодо наявності дихання, вважати, що його немає, та розпочати проведення серцево-легеневої реанімації;

- якщо поблизу є автоматичний зовнішній дефібрилятор - одразу його принести чи доручити це оточуючим, паралельно проводити непрямий масаж серця та штучне дихання (або лише масаж серця за неможливості проведення штучного дихання). Співвідношення натискань на грудну клітку до штучних вдихів 30:2, починаючи з натискань на грудну клітку;

- за можливості кожні 2 хв проводити заміну рятувальника, який виконує компресію грудної клітки;

- продовжувати серцево-легеневу реанімацію до появи дихання у пацієнта, його рухів, відкривання очей; до прибуття бригади екстреної медичної допомоги (ЕМД), до настання фізичного виснаження рятувальника;

- після успішної реанімації - перевести пацієнта у стабільне положення на боці й чекати на прибуття бригади (ЕМД), при цьому постійно контролювати наявність дихання (перевірка пульсу обов'язкова тільки для медичного персоналу);

- не залишайте пацієнта без нагляду.

Іноді передозування настає не відразу: спочатку після ін'єкції людина почуває себе нормально, а пізніше блідне, падає і задихається [2].

що робити?

1. Негайно викликати карету швидкої допомоги.

2. Покласти людину на бік або на живіт, щоб вона не захлинулася при блюванні чи не проковтнула язик.

3. Якщо в роті $\epsilon$ блювотні маси, їх потрібно вичистити звідти ганчіркою, намотаною на палець, інакше вона задихнеться.

4. Термосити їі, не давати заснути, поки вона остаточно не отямиться.

5. Перевірити подих і пульс - якщо дихання $\epsilon$, тоді ребра будуть підніматися й опускатися, щоб перевірити пульс, покласти пальці на шию збоку від кадика при передозуванні пульс дуже слабкий.

6. Якщо дихання і пульс $є$, продовжувати термосити iï, давати нюхати нашатирний спирт. 
7. Якщо дихання і пульсу немає - потрібно робити штучне дихання і масаж серця.

Людина може померти при передозуванні за 10 хв, тому дуже важливо не панікувати, а швидко розібратися у чому справа і діяти. Не залишати їі поки не приїде бригада екстреної медичної допомоги.

Надати домедичну допомогу людині у невідкладному стані зобов'язані:

- рятувальники аварійно-рятувальних служб;

- працівники державної пожежної охорони;

- поліцейські;

- фармацевтичні працівники;

- провідники пасажирських вагонів;

- бортпровідники та інші особи, які не мають медичної освіти, але за своїми службовими обов'язками мають навички надання домедичної допомоги;

- члени сім'ї постраждалих;

- соціальні працівники;

- особи, які стали свідками передозування опіоїдами або його наслідків.

Особи, зобов'язані надавати домедичну допомогу відповідно до статті 12 Закону України «Про екстрену медичну допомогу» від 05.07.2012 р. № 5081-VI, можуть застосовувати антидот (налоксон), якщо вони пройшли відповідне навчання, а також якщо антидот входить до складу аптечки [3].

Перед тим, як вводити препарат постраждалому, дізнайтеся, чи належить він до осіб із підвищеним ризиком передозування опіоїдами. У цьому вам допоможе пам'ятка.

Особами з підвищеним ризиком передозування $\epsilon$ :

- особи, які залежні від опіоїдів, зокрема ті, які мають досвід передозування та/або знижену толерантність (після детоксикації, звільнені від ув'язнення, припинення лікування);

- особи, які застосовують опіоїди за призначенням, зокрема у підвищених дозах;

- особи, які застосовують опіоїди разом зі снодійними та седативними речовинами;

- особи, які застосовують опіоїди та мають тяжкі захворювання (ВІЛ, захворювання печінки або легень, депресія);

\section{СПИСОК ЛІТЕРАТУРИ}

1. Про затвердження порядку надання домедичної допомоги особам при невідкладних станах : наказ МОЗ від 16.06.2014 р. № 398.

2. Про внесення змін до наказу Міністерства охорони здоров'я України від 16 червня 2014 р. № 398 : наказ МОЗ від 08.10.2018 р. № 1833.
- особи, які вживають наркотичні засоби шляхом ін'єкцій, особливо при першому застосуванні;

- особи, які спільно проживають із особами, залежними від опіоїдів [2].

Якщо ви надаєте постраждалому необхідну допомогу і використовуєте ін'єкційну форму антидоту (налоксону), вводьте його у дозуванні від 0,4 до 2 мг внутрішньом'язово. Якщо використовуєте інтраназальну форму - 2 мг у носову порожнину (розпилити 1 мл антидоту (налоксону) у дозі 1 мг/мл у кожну ніздрю) [2].

Оптимальним методом введення антидоту (налоксону) особами, які не $\epsilon$ медичними працівниками, $\epsilon$ інтраназальне введення (в порожнину носа без порушення цілісності шкірних покривів) для розпилення на слизову оболонку. Якщо використовувати розчин для ін'єкцій, внутрішньом'язову ін'єкцію необхідно робити у зовнішню поверхню плеча або стегна [2].

Ми розповіли тільки про передозування опіоїдами - передозування іншими наркотичними препаратами та речовинами виглядає по-іншому.

Висновки. Держави мають бути безкомпромісними у боротьбі з розповсюдженням наркотиків. Вони мають максимально забезпечувати уповноважені органи як інформацією, так і технічною базою. Окрім того, необхідно активніше залучати науковців та фахівців із сучасних технологій. Насамперед задля протидії продажам у так званому «Даркнеті» - анонімній тіньовій частині світової мережі.

Ця вимога об'єктивно зумовлена міжнародною природою злочину розповсюдження наркотиків. Адже, як правило, речовину вирощують в одній країні, розфасовують в другій та збувають у третій. І лише спільні зусилля можуть розірвати цей порочний ланцюг.

Варто відзначити, що наша держава вже закріпила гуманістичні тенденції у боротьбі з наркоманією у Національній стратегії щодо наркотиків - 2020. Сподіваємось, що ці наміри будуть втілені у життя та допоможуть розв'язати злободенну для країни проблему наркоманії.

3. Про екстрену медичну допомогу : Закон України від 05.07.2012 p. № 5081-VI. 